\title{
The Role Of The Head Of Public Health Graduate and Non Public Health Graduate Heads In Improving Managerial Abilities: Case Study of Puskesmas Bulu and Puskesmas Polokarto
}

\author{
Budhi Rahardjo ${ }^{1 *}$, Suryo Ediyono ${ }^{1}$, Nur Ani' ${ }^{2}$, Munika Saraswati ${ }^{2}$ \\ ${ }^{1}$ Universitas Sebelas Maret, Surakarta, Indonesia \\ ${ }^{2}$ Universitas Veteran Bangun Nusantara, Indonesia \\ *budhirahardjo8@gmail.com
}

\begin{abstract}
The Managerial ability has an essential role in the leadership of a Puskesmas organization. The administration of the head of the Puskesmas in curriculum management includes SKM graduates rather than non-SKM graduates. Puskesmas in Sukoharjo Regency led by SKM totaled $8.3 \%$ Puskesmas and $91.7 \%$ Puskesmas led by non-SKM. The result was conducted in June 2020. This type of research is descriptive qualitative with a case study approach method. The subjects of this study were the Head of the Human Resources Division of the Sukoharjo Health Service, the Head of the Puskesmas, and the Puskesmas staff. Data collection techniques include direct observation, in-depth interviews, and documentation study. This study's data analysis stage in this study was data collection, data analysis, data reduction, data presentation, and conclusion drawing. The results of this study showed that the Puskesmas headed by SKM graduates showed more role in managerial ability than the Head of Non-SKM Puskesmas. Public health centers do not have to be led by a doctor, but SKM graduates can also show the Puskesmas. It is recommended that the Sukoharjo Regency Government and the Sukoharjo District Health Office consider the appointment of the Head of the Puskesmas because SKM leaders are not inferior to non-SKM leaders, even in terms of managerial SKM leaders carry out more administrative roles.
\end{abstract}

Keywords : Graduates, Head of Public Health Center, Managerial Ability 


\section{STRADA Jurnal Ilmiah Kesehatan}

DOI: $10.30994 /$ sjik.v9i2.538

ISSN: 2252-3847 (print); 2614-350X (online)

Vol.9 No.2 November 2020 Page.1807-1813

\section{BACKGROUND}

Leadership is the ability and skills of a person who supports his position as head of a work unit to influence other's behavior, especially subordinates, to think and act so that favorable action can contribute significantly to achieving organizational goals. The performance of health leaders and personnel is a critical issue to promote and maintain healthy development. Health development to increase the ability to live healthy for everyone to improve health status.

There are several health services in Indonesia, one of which is the Puskesmas. Based on a 2010 study by Dr. Joko Utomo, MM, Puskesmas in Central Java Province with 176 Puskemas as respondents showed that the percentage of origin of available positions was $82.9 \%$, dentists $11.4 \%$, SKM 5.7\%. Based on the interview results, when serving as Head of the Puskesmas, open positions were not given by the Health Office even though they did medical service work at the Puskesmas and the Head of the Puskesmas received a structural allowance. The head of the Non-SKM Puskesmas in leading cannot focus on the structure because he has multiple medical services duties.

Sukoharjo Regency is one of the districts in Central Java Province. Based on data from the Health Office, there are 12 health centers in Sukoharjo district. Sukoharjo Regency has implemented the community health center (puskesmas) to become the regional technical implementation unit (UPTD) of the Puskesmas. Puskesmas led by SKM totaled $8.3 \%$ Puskesmas and 91.7\% Puskesmas led by non-SKM. Based on interviews with the head of HRK section of the Sukoharjo Health Office, the leadership of the Head of the Puskesmas in the direction of management is more capable of the Head of the Puskesmas with an educational background of SKM than those who are not.

According to the Regulation of the Minister of Health of the Republic of Indonesia Number 43 of 2019 concerning Community Health Centers article 44 paragraph 2d, the Head of the Puskesmas must meet the requirements, one of which is to have management skills in the field of public health. This policy provides an opportunity for SKM to become the Head of the Puskesmas in Sukoharjo Regency. It has not been accompanied by a comprehensive evaluation of the resulting performance, both from the head of the Puskesmas. They graduated from SKM and Non-SKM to see the potential of each leader.

Based on data on problems in Central Java Province and data from the Sukoharjo Health Office, this study aims to determine the managerial abilities of the SKM and nonSKM Puskesmas Heads based on the ten administrative roles of the Puskesmas Heads.

\section{METHODS}

This type of research is qualitative research with a case study approach, where this method aims to obtain in-depth data, data that contains meaning. The subjects of this study were the Head of the HRK Section of the Health Officer and the Head of the General and Personnel Section of the Sukoharjo Health Office and for triangulation data, namely the Head of Bulu and Polokarto Puskesmas, Head of Administration, Administrative Staff, and PJ UKM. Data collection techniques are direct observation, in-depth interviews (in-dept interview), documentation studies. This study's data analysis stage in this study was data collection, data analysis, data reduction, data presentation, and conclusion drawing. 


\section{STRADA Jurnal Ilmiah Kesehatan}

DOI: $10.30994 /$ sjik.v9i2.538

ISSN: 2252-3847 (print); 2614-350X (online)

Vol.9 No.2 November 2020 Page.1807-1813

\section{RESULTS}

The results of this study describe the interpersonal roles of the Heads of SKM and NonSKM Puskesmas, and the Informational Role of the Heads of SKM and non-SKM Puskesmas. The results can be described in the following table:

\section{Table 1}

Interpersonal Roles of Heads of SKM and Non-SKM Puskesmas

\begin{tabular}{|c|c|c|c|}
\hline No. & Interpersonal Roles & Head of Puskesmas SKM & Head of Non-SKM Puskesmas \\
\hline \multirow[t]{2}{*}{1} & Figure & $\begin{array}{l}\text { More focus on office } \\
\text { matter's }\end{array}$ & $\begin{array}{l}\text { Ativities in and outside the } \\
\text { building are balanced }\end{array}$ \\
\hline & & $\begin{array}{l}\text { Many activities outside the } \\
\text { building are more patient- } \\
\text { focused }\end{array}$ & \\
\hline \multirow[t]{3}{*}{2} & Leader & $\begin{array}{l}\text { Leadership emphasizes } \\
\text { more the main tasks and } \\
\text { functions }\end{array}$ & $\begin{array}{l}\text { Leadership places more } \\
\text { emphasis on integrity and rules }\end{array}$ \\
\hline & & $\begin{array}{l}\text { Making staff as work team, } \\
\text { not subordinates }\end{array}$ & Teamwork but not so close \\
\hline & & $\begin{array}{l}\text { It is easier to build cross- } \\
\text { sectoral relationships }\end{array}$ & $\begin{array}{l}\text { It's easy to find cross-sector } \\
\text { relationships }\end{array}$ \\
\hline 3 & Liasion & $\begin{array}{l}\text { Has easy communication } \\
\text { with cross-sector }\end{array}$ & $\begin{array}{l}\text { It's a little challenging to } \\
\text { communicate across sectors }\end{array}$ \\
\hline
\end{tabular}

Source : Primer Data In-depth Interview (2019)

Based on table1, it describes the interpersonal roles of puskesmas heads, who come from SKM and Non-SKM education. In essence, the Head of the Non-SKM Puskesmas has played a significant role in interacting with subordinates and the surrounding environment, but he prioritizes patients rather than office affairs. Meanwhile, the information role of the head of the SKM and Non-SKM Puskesmas can be seen in Table 2 below :

\section{Table 2}

Informational Role of Head of SKM and Non-SKM Puskesmas

\begin{tabular}{|c|c|c|c|}
\hline No. & Informational Role & Head of Puskesmas SKM & Head of Non-SKM Puskesmas \\
\hline 1. & Monitoring & $\begin{array}{l}\text { More frequent direct } \\
\text { surveillance monitoring }\end{array}$ & $\begin{array}{l}\text { Much supervision is left to the } \\
\text { coordinator }\end{array}$ \\
\hline 2. & $\begin{array}{l}\text { Information } \\
\text { Spreader }\end{array}$ & $\begin{array}{l}\text { Gather and disseminate } \\
\text { information from time to } \\
\text { time }\end{array}$ & $\begin{array}{l}\text { Collect and disseminate } \\
\text { information from time to time }\end{array}$ \\
\hline & Spokesman & $\begin{array}{l}\text { As much as possible in an } \\
\text { event inside or outside the } \\
\text { building to be a } \\
\text { spokerperson, for example, } \\
\text { there is a meeting, disease } \\
\text { counselling, automatically } \\
\text { as an opening and a little } \\
\text { speaker }\end{array}$ & $\begin{array}{l}\text { Outside the building for sure, but } \\
\text { if you cant if there are new needs } \\
\text { for other people, if it's the head } \\
\text { inside, for example you cant } \\
\text { deputize the head of } \\
\text { administration }\end{array}$ \\
\hline
\end{tabular}

Source : Primer Data In-depth Interview (2019) 


\section{STRADA Jurnal Ilmiah Kesehatan}

DOI: $10.30994 /$ sjik.v9i2.538

ISSN: 2252-3847 (print); 2614-350X (online)

Vol.9 No.2 November 2020 Page.1807-1813

Based on table 2, the role of the Head of the Puskesmas can be seen from the role of observer, disseminator of information and spokesperson. Meanwhile, the role in decision making can be seen in table 3 below:

Table 3

\begin{tabular}{|c|c|c|c|}
\hline No. & $\begin{array}{l}\text { The Role of } \\
\text { the Decision Maker }\end{array}$ & $\begin{array}{c}\text { Head of Puskesmas } \\
\text { SKM }\end{array}$ & $\begin{array}{l}\text { Head of Non-SKM } \\
\text { Puskesmas }\end{array}$ \\
\hline 1. & Enterpreneur & $\begin{array}{l}\text { Structural and } \\
\text { routine in nature }\end{array}$ & $\begin{array}{l}\text { Structural and routine in } \\
\text { nature }\end{array}$ \\
\hline 2. & Fixer & $\begin{array}{l}\text { In breaking the usual } \\
\text { problem with kinsip }\end{array}$ & $\begin{array}{l}\text { Tend to beNon SKM } \\
\text { using the rules }\end{array}$ \\
\hline 3. & Resource Divider & $\begin{array}{l}\text { In placing are less } \\
\text { assertiveemployees }\end{array}$ & $\begin{array}{l}\text { More assertive in placing } \\
\text { employees }\end{array}$ \\
\hline 4. & Negosiator & $\begin{array}{l}\text { Use more good } \\
\text { communication }\end{array}$ & $\begin{array}{l}\text { Good communication is } \\
\text { the key }\end{array}$ \\
\hline
\end{tabular}

Source : Primer Data In-depth Interview (2019)

Based on table 3, it can be seen that the role of the Head of Puskesmas decision makers from SKM and Non SKM educational backgrounds can be differentiated based on entrepreneurial traits, problem solvers, resource dividers and negotiators.

\section{DISCUSSION}

\section{Interpersonal Roles}

The head of the SKM Puskesmas has played a significant role in interacting with subordinates and the surrounding environment, always giving direction to subordinates and always motivating employees. Besides, the Head of Puskesmas builds good communication with external parties to establish cross-sector cooperation. As a liaison with external parties, the head of the Puskesmas has the main key, namely good communication. The head of the non-SKM Puskesmas has played a significant role in interacting with subordinates and the surrounding environment, but he prioritizes patients rather than office affairs. Rim besides addition, the Head of Puskesmas builds good communication with external parties to establish cross-sector cooperation. As a liaison with external parties, the head of the Puskesmas has the primary key, namely good communication.

The head of the Puskesmas carries out many activities as the main character. This is because the head of the SKM Puskesmas does'nt have dual duties between office affairs and patient handling. As a leader, the head of the Puskesmas, SKM emphasizes more on the main tasks and functions of the staff so that they do not seem to be distace between the leader and the subordinates, because the main characteristic of the leader is that they must be appropriate and must be accepted by their subordinates. The head of the SKM Puskesmas mostly communicates two-way with his staff. This is used to establish good communication between superiors and subordinates such as not being distant and being 


\section{STRADA Jurnal Ilmiah Kesehatan}

DOI: $10.30994 /$ sjik.v9i2.538

ISSN: 2252-3847 (print); 2614-350X (online)

Vol.9 No.2 November 2020 Page.1807-1813

impressed as a work team so that it is hoped that openness can make it easier for staff to carry out tasks according to organizational goals, which are different from heads of nonSKM Puskesmas who are still at a distance from their staff because they represent more to the coordinator. In terms of monitoring and reporting.

\section{Informational Role}

The head of the SKM puskesmas has the role of collecting and analyzing information, where if the head of the health center receives information, he immediately disseminates it even though it is midnight. The head of the puskesmas also acts as a monitor.He often performs direct monitoring (sudden inspection). The head of the puskesmas is also the spokesperson for events inside and outside the building. The head of the non-SKM puskesmas has the role of collecting and analyzing information, Where if the head of the puskesmas receives information directly disseminates it and if there is something the staff immediately reports. The head of the puskesmas also acts as a monitor, but it is more left up to the respective coordinators, even though if he is loose he also carries out inspections outside the building. The head of the puskesmas is also the spokesperson for events inside and outside the building, for example, the head of the administration cannot represent him.

The head of the SKM Puskesmas in carrying out the supervisory role is carried out directly because he has no dual role, in contrast to the head of the non-SKM puskesmas, who leaves more to the coordinator because he remembers his dual roles as a leader and a doctor. The leadership of the head of the puskesmas as disseminators of information between the SKM and non-SKM heads is classified as both collecting information and disseminating it from time to time. However, in terms of leeway time outside the building, the heads of non-SKM Puskesmas mostly belong to them because they don't have dual duties between patients and office affairs. In carrying out activities, the role of information is related to the role of spokesperson. The leader in his role as spokesperson must communicate his role to influential people. The spokesperson is one of the factors to assess the quality of a leader.

\section{The Role of the Decision Maker}

The head of the SKM Puskesmas is responsible for decision making, every decision in the work environment is taken jointly, but if it is an emergency, the head who makes the decision. The head also plays a role in solving problems in the work environment.Every time there is a problem the head always provides input and solutions. In addition, to support the performance of the puskesmas environment, it requires human resources who are experts in their fields, the human resources at the Bulu Puskesmas are in accordance with an educational background, but there are in the Administration section that are not appropriate. To cooperate with outsiders requires negotiation, the way the head of the puskesmas is to achieve good negotiations, namely communication. The head of the nonSKM puskesmas is responsible for decision making, every decision in the work environment is taken jointly, but if it is an emergency, the head must take the decision. The head also plays a role in solving problems in the work environment, every time there is a problem the head always provides input and solutions. In addition, to support the performance of the Puskesmas environment, there is a need for human resources who are experts in their fields. Some Human Resourse (HR) at the Polokarto Puskesmas are not in accordance with their educational background. To collaborate with outsiders requires 


\section{STRADA Jurnal Ilmiah Kesehatan}

DOI: $10.30994 /$ sjik.v9i2.538

ISSN: 2252-3847 (print); 2614-350X (online)

Vol.9 No.2 November 2020 Page.1807-1813

negotiation, the way the head of the puskesmas is to achieve good negotiations, namely communication.

In the matter of decision making, the head of the SKM puskesmas is less assertive in assigning employees, compared to the head of the non-SKM puskesmas because this is because most of the head of the SKM puskesmas are native to the area where they work, so they know more about the community in the area. Leaders are required to improve human resource capabilities so that they can be more effective in carrying out their duties and responsibilities as administrators in an organization more firmly related to the allocation of resource sharing in the analysis according to their respective workloads. Meanwhile, in solving the problem, the head of the SKM puskesmas is more of a family nature, discussed together by finding the best solution, in contrast to the head of the nonSKM puskesmas which is more related to existing regulations.

\section{Should the Head of the Puskesmas be led by a Doctor?}

Based on the description above, the managerial role has a higher power carried out by the Head of the SKM Puskesmas. Where there is a role for leaders, information disseminators and decision makers. These results indicate that the head of puskesmas SKM performed more managerial roles than non-SKM, both based on the opinion of the head and puskesmas staff. A doctor plays more of a role in patient management, so office affairs are second nature. The strengths of the head of the SKM puskesmas compared to non-SKM in improving the managerial abilities of the puskesmas are: 1) more focused on carrying out every activity inside and outside the building; 2) carrying out leadership emphasizes the main tasks and functions of two-way communication so that staff is open; 3) have a good network across sectors.

\section{CONCLUSION}

The Interpersonal Role of SKM Puskesmas heads compared to non-SKM heads is higher because the SKM puskesmas heads do not have multiple duties so that they can carry out the role of leader more optimally. In carrying out the leadership, the head of the Puskesmas SKM uses openness so that it does not appear to be a distance between superiors and subordinates, but rather like a work team.

Informational Role The head of the SKM Puskesmas has more time to conduct direct supervision of his staff than the head of the non-SKM Puskesmas who gives more control to subordinates. The leader in his role as a spokesperson must communicate his role to influential people because the spokesperson is one of the factors to assess the quality of a leader.

The role of decision makers for the head of the SKM Puskesmas is less firm than the head of the non-SKM puskesmas, especially in terms of the allocation of resources which is still very less firm.

\section{REFERENCES}

Alfiani,

$\mathrm{N}$.

(2015).

Kepemimpinan. http://kepemimpinan456.blogspot.com/2015/04/kepemimpinan.html? $\mathrm{m}=1$. diakses pada 20 Agustus 2020.

Aulawi, A., Ahmad, R. A. dan Hasanbasri, M. (2018) "Peran kepala puskesmas SKM dan non SKM dalam meningkatkan kemampuan manajerial puskesmas di kabupaten Oku Timur," Berita Kedokteran Masyarakat, 32(9), hal. 339. doi: $10.22146 / \mathrm{bkm} .7552$. 


\section{STRADA Jurnal Ilmiah Kesehatan}

DOI: $10.30994 /$ sjik.v9i2.538

ISSN: 2252-3847 (print); 2614-350X (online)

Vol.9 No.2 November 2020 Page.1807-1813

Kemenkes RI. (2019). Permenkes No 43 Tahun 2019 tentang Puskesmas. Jakarta.

Moleong.(2007) Metode Penelitian

Kualitatif.

https://www.coursehero.com/file/p2bna65/Menurut-Lexy-J-Moleong-prosesanalisis-data-kualitatif-dimulai-dengan-menelaah/ . diakses pada 25 Juli 2020

Notoadmojo. (2012). Metode penelitian Kualitatif. Skripsi Universitas Muhammadiyah Yogyakarta.

Sugiyono. (2014). Metode penelitian . Malang : Skripsi Universitas Muhammadiyah

Malang.

Utomo, Joko. (2013). Kepuasan Kerja dan Kinerja Pemimpin. Yogyakarta : Pandiva buku Nutrisi peradaban. 